\title{
Reconciling Native Son and Native Daughters
}

(RADICAL TEACHER NO.34, 1988)

by Onita Estes-Hicks

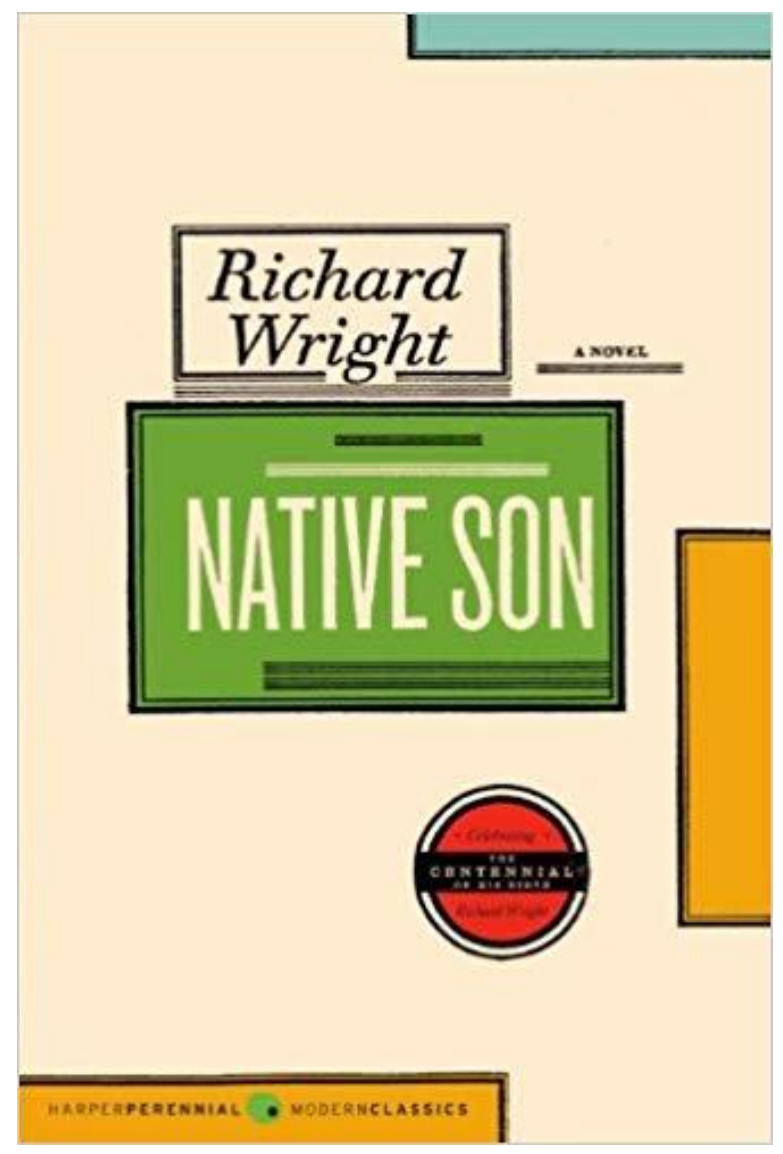

NATIVE SON, RICHARD WRIGHT (HARPER, 1940) 
$\mathrm{F}$ ollowing several taxing class sessions on Native Son this past semester, once again I questioned the wisdom of teaching Richard Wright's novel in the inhospitable climate of rising racism. Even on the campus of a self-styled progressive liberal arts college in New York, the hostile responses of white students, the defensive remarks of black students, and the tensions between the two groups of undergraduates mirrored the growing intolerance and tensions of these trying times.

Under optimum circumstances, teaching Native Son is not an easy task. Published in 1940, the novel gave birth to Bigger Thomas, an illiterate, nineteen-year-old black youth. Bigger lives with his mother and siblings in a rat- infested, one-room apartment on Chicago's Southside. Angry and fearful, poor and unemployed, he takes a job as chauffeur to the wealthy white Dalton family and enters the alien and imposing world of Chicago's prestigious Hyde Park. Conditioned by his fear, Bigger accidentally murders Mary Dalton, the spoiled daughter of the family.

Then, on the run, he deliberately kills Bessie, his loyal and exploited black girlfriend, fearing that she will lead police to his hiding place. With two killings against him and very little in the way of personal attributes to recommend him, Bigger is not an easy character to discuss or explain. Blinded by their own illusion of freedom and free choice, today's students readily reject the sociological defense which Wright painstakingly builds. Discarding Wright's humane sociology, white students recoil from the novel, their fear of black violence confirmed in the murders Bigger commits. Equally resistant to Wright's unravelling of Bigger's dehumanization, black students see Bigger's murder of Mary Dalton as an act of just revenge, nemesis visiting Hyde Park, avenging it for creating the Southside ghetto.

This past semester, the arduous task of teaching Native Son was made more difficult by polar opposites in the classroom. A young white student, always prepared and vocal, registered her resistance by refusing to complete the text of Native Son, the one black book on the reading list. She tried to take refuge behind her abhorrence of violence; however, under probing, her intolerance surfaced in a spontaneous comment -- "I'm sick and tired of it." The "it" here referred to the issue of black life, even when that life was reflected in literature. This student's extra-literary motives were shared by a black counterpart, an articulate and ambitious young woman, who, in contrast, had read the text intently, using Wright for her own purposes. She displayed an eagerness for discussion which matched the other student's determined silence. Misreading Wright and misunderstanding Bigger, the black student spoke eloquently in Bigger's defense and supported his crimes.

In concealed dismay, I reminded Bigger's attacker of her former willingness to suspend disbelief and work through a text, chastening her for dismissing Wright without reading him. I then asked Bigger's supporter to make a defense of his murder of Bessie, his hardworking, poignant black girlfriend. Could a humane writer advocate acts of murder? Weren't literary texts imaginative trips into cultures and spaces beyond our own? Why was Wright's depiction of an urban ghetto relevant today? Did Native Son contain any truths for their generation? Under probing, the students pondered these and other issues, but resolved nothing, remaining frozen in their racially determined molds. Frustrated, once again I readied myself to abandon Wright, haunted by the sense of alienating students when the semester yet had another one-third duration.

Shortly after our discussion of Wright, the case of Larry Davis erupted in New York. Davis, an illiterate, twenty-yearold Bronx youth, bears uncanny resemblances to his fictional counterpart. Accused of the murder of drug dealers, Davis eluded police in a massive manhunt which could have come from the pages of Native Son. Like Bigger, Davis sought shelter in the ghetto, bringing scores of police to the local neighborhood. His widespread publicity matched the coverage of Bigger's Southside manhunt. As had happened in Chicago, New Yorkers were taking sides and, while Davis did not write a ransom note which further publicized his exploits, his alleged call to a talk show host galvanized attention. Like Bigger, Davis could not, would not give up, convinced his case would not receive justice. The manhunt became the talk of the town.

One morning following the Davis phone call, a normally shy and retiring student broached the case in class. This older woman, a returning housewife with two teenage daughters, had heard the telephone call and began making connections between Larry Davis and Bigger Thomas. Transfixed by the similarities between the two young men, she lit up as she began expressing a new understanding, not only of Bigger Thomas, but also of the humanizing capabilities of literature. "Had I not read this book," she explained, "I would have no way of entering into the mind of a Larry Davis." This sudden convert to Wright continued to address the class, displaying a self-confidence newly discovered. "I was up all night, bothered by that Davis boy, understanding what it meant for him to be cooped up somewhere in hiding, because I had read what Wright described of Bigger's situation in hiding." Finally, she made connections in the motives of the two, which brought together lessons of literature and life. "As Bigger lived in wealthy Chicago and ached to possess some of the good things he saw but had no way to get by legitimate means, so too Larry Davis, a school dropout, unable to read or write, was surrounded by all this wealth in New York and went about getting some of it in his own way."

The student's sincerity as well as her insights gave new meaning to the novel, and ushered in one of those unforgettable moments in a classroom when isolated bodies claim their rightful identity as a class: a group united in a common pursuit of knowledge. The undergraduate who had placed her defense of Bigger in a philosophy of revenge finally saw the flaws in her position and decided to explore the theme of revenge in a paper. The classmate who had not completed the text realized her mistake in having missed the opportunity to grasp the plight of another individual; she determined to finish the novel. 
Leaving class, I gave thanks that the times had conspired to help me redeem Wright and bring his special message home to a new group of students. Perhaps, I thought, I would once again venture with Wright and risk the dangers of making a way for his uncanny Native Son. Once again life had proclaimed the necessity of art in reconciling Native Son and native daughters. 